\title{
World Health Organization, radiofrequency radiation and health - a hard nut to crack (Review)
}

\author{
LENNART HARDELL \\ Department of Oncology, Faculty of Medicine and Health, Örebro University, SE-701 82 Örebro, Sweden
}

Received April 1,2017; Accepted June 6, 2017

DOI: 10.3892/ijo.2017.4046

\begin{abstract}
In May 2011 the International Agency for Research on Cancer (IARC) evaluated cancer risks from radiofrequency (RF) radiation. Human epidemiological studies gave evidence of increased risk for glioma and acoustic neuroma. $\mathrm{RF}$ radiation was classified as Group $2 \mathrm{~B}$, a possible human carcinogen. Further epidemiological, animal and mechanistic studies have strengthened the association. In spite of this, in most countries little or nothing has been done to reduce exposure and educate people on health hazards from RF radiation. On the contrary ambient levels have increased. In 2014 the WHO launched a draft of a Monograph on RF fields and health for public comments. It turned out that five of the six members of the Core Group in charge of the draft are affiliated with International Commission on Non-Ionizing Radiation Protection (ICNIRP), an industry loyal NGO, and thus have a serious conflict of interest. Just as by ICNIRP, evaluation of non-thermal biological effects from RF radiation are dismissed as scientific evidence of adverse health effects in the Monograph. This has provoked many comments sent to the WHO. However, at a meeting on March 3, 2017 at the WHO Geneva office it was stated that the WHO has no intention to change the Core Group.
\end{abstract}

\section{Contents}

1. Introduction

2. The WHO fact sheet

3. The WHO EMF project

4. WHO radio frequency fields: Environmental health criteria monograph

5. Human Health Effects of Non-Ionizing Radiation - Informal meeting at WHO March 3, 2017

Correspondence to: Dr Lennart Hardell, Department of Oncology, Faculty of Medicine and Health, Örebro University, SE-701 82 Örebro, Sweden

E-mail: lennart.hardell@regionorebrolan.se

Key words: electromagnetic fields, EMF, radiofrequency radiation, public exposure, cancer, WHO, monograph, conflict of interest, ICNIRP, non-thermal effects, health risks
6. Exposure to RF radiation within the WHO building in Geneva

7. Concluding remarks

\section{Introduction}

The use of wireless digital technology has grown rapidly during the last couple of decades (http://www.itu.int/en/ ITU-D/Statistics/Documents/facts/ICTFactsFigures2016.pdf). During use, mobile phones and cordless phones emit radiofrequency $(\mathrm{RF})$ radiation. The brain is the main target organ for RF emissions from the handheld wireless phone $(1,2)$. An evaluation of the scientific evidence on the brain tumour risk was made in May 2011 by the International Agency for Research on Cancer (IARC) at the World Health Organization (WHO). IARC is independently financed and has its own governing and scientific councils, which WHO staff only attend as observers (http://www.who.int/ionizing_radiation/ research/iarc/en/).

Epidemiological studies provided supportive evidence of increased risk for head and brain tumours, i.e., acoustic neuroma and glioma. The working group reached the conclusion that RF radiation from devices that emit non-ionizing $\mathrm{RF}$ radiation in the frequency range $30 \mathrm{kHz}-300 \mathrm{GHz}$, is a Group 2B, i.e. a 'possible', human carcinogen $(3,4)$. Later studies have corroborated these findings and have thus strengthened the evidence (5-8).

Several laboratory studies have indicated mechanisms of action for RF radiation carcinogenesis such as on DNA repair, oxidative stress, down regulation of mRNA and DNA damage with single strand breaks (9-13). A report was released from The National Toxicology Program (NTP) under the National Institutes of Health (NIH) in USA on the largest ever animal study on cell phone RF radiation and cancer (14). An increased incidence of glioma in the brain and malignant schwannoma in the heart was found in rats. Acoustic neuroma or vestibular schwannoma is a similar type of tumour as the one found in the heart, although benign. Thus, this animal study supported human epidemiological findings on RF radiation and brain tumour risk (8).

The IARC cancer classification includes all sources of $\mathrm{RF}$ radiation. The exposure from mobile phone base stations, Wi-Fi access points, smart phones, laptops and tablets can be long-term, sometimes around the clock, both at home and at 
school. For children this risk may be accentuated because of a cumulative effect during a long lifetime use (15). Developing and immature cells can also be more sensitive to exposure to $\mathrm{RF}$ radiation (9).

In spite of the IARC evaluation little has happened to reduce exposure to RF fields in most countries. On the contrary, with new technology increasing environmental exposure levels are found as in measurements of ambient RF radiation at e.g. Stockholm Central Station and Stockholm Old Town in Sweden $(16,17)$. The exposure guideline used by many agencies was established in 1998 by the International Commission on Non-Ionizing Radiation Protection (ICNIRP) and was based only on established short-term thermal (heating) effects from RF radiation neglecting nonthermal biological effects (18). The heating effects arise when radiation is so high that it warms up the whole body by $1^{\circ} \mathrm{C}$ or more after $30 \mathrm{~min}$ exposure at $4 \mathrm{~W} / \mathrm{kg}$ specific absorption rate. The guidelines are set with a safety factor of 50 for the general public (http://www.who.int/peh-emf/about/ WhatisEMF/en/index4.html).

Basis for limiting exposure according to ICNIRP: 'Only established effects were used as the basis for the proposed exposure restrictions. Induction of cancer from long-term EMF exposure was not considered to be established, and so these guidelines are based on short-term, immediate health effects such as stimulation of peripheral nerves and muscles, shocks and burns caused by touching conducting objects, and elevated tissue temperatures resulting from absorption of energy during exposure to EMF. In the case of potential long-term effects of exposure, such as an increased risk of cancer, ICNIRP concluded that available data are insufficient to provide a basis for setting exposure restrictions, although epidemiological research has provided suggestive, but unconvincing, evidence of an association between possible carcinogenic effects.' (http://www.icnirp.org/cms/upload/ publications/ICNIRPemfgdl.pdf).

This is an exceptional statement by ICNIRP, and found in many statements of groups following the ICNIRP philosophy like the AGNIR and on the WHO EMF Project's homepage as well, that epidemiology found 'suggestive, but unconvincing' evidence. What is convincing or not is so decidedly subjective that no scientific body will ever make this as a basis for a decision. There might be gaps in knowledge that make it difficult to decide about the mechanisms that underlie an observation and even an observation could be considered unreliable but the conviction must not enter a rational discourse about a scientific issue.

The guidelines were updated in 2009 but still do not cover cancer and other long-term or non-thermal health effects. ICNIRP gives the guideline 2 to $10 \mathrm{~W} / \mathrm{m}^{2}$ for $\mathrm{RF}$ radiation depending on frequency, thus only based on a short-term immediate thermal effect (19). ICNIRP is a private organisation (NGO) based in Germany. New expert members can only be elected by members of ICNIRP. Many of ICNIRP members have ties to the industry that is dependent on the ICNIRP guidelines. The guidelines are of huge economic and strategic importance to the military, telecom/IT and power industry.

In contrast to ICNIRP, the BioInitiative Reports from 2007 and updated in 2012, based the evaluation also on non-thermal health effects from RF radiation $(20,21)$. The scientific benchmark for possible health risks was defined to be 30 to $60 \mu \mathrm{W} / \mathrm{m}^{2}$. Thus, using the significantly higher guideline by ICNIRP gives a 'green card' to roll out the wireless digital technology thereby not considering non-thermal health effects from RF radiation. Numerous health hazards are disregarded such as cancer (8), effects on neurotransmitters and neuroprotection (22,23), blood-brain-barrier (24,25), cognition (26-29), psychological addiction (30-32), sleep (33-36), behavioral problems (37-41) and sperm quality $(13,42,43)$.

No doubt the IARC decision started a world-wide spinning machine to question the evaluation. It was similar to the one launched by the tobacco industry when IARC was studying and evaluating passive smoking as a carcinogen in the 1990s (44). Sowing confusion and manufacturing doubt about scientific facts is a well-known strategy used by the tobacco and other industries $(8,45-48)$.

\section{The WHO fact sheet}

A Fact Sheet from WHO issued in June 2011 shortly after the IARC cancer classification in May 2011 stated that 'To date, no adverse health effects have been established as being caused by mobile phone use' (http://www.who.int/mediacentre/factsheets/fs193/en/). This statement was not based on scientific evidence at that time on a carcinogenic effect from RF radiation. It was certainly a remarkable conclusion by WHO since IARC is part of WHO although seemingly independent, see above.

However, it is also important to note that the statement in the Fact Sheet does not fully contradict the IARC statement. A Group 2B carcinogen is considered by IARC as an agent where an association with cancer has been detected that can be causally interpreted but for which chance, bias and confounding cannot be ruled out with sufficient scientific certainty. Hence, the statement in the Fact Sheet is in line with IARC's classification although, of course, it will rather be understood as a full dismissal of claims of harm.

In the WHO Fact Sheet it was also stated that 'WHO will conduct a formal risk assessment of all studied health outcomes from radiofrequency fields exposure by 2012.' The pertinent question is why WHO was so keen to make a new risk evaluation shortly after the IARC evaluation. It was hardly expected that new studies would be published in short time changing the classification of RF radiation as a possible, Group 2B, human carcinogen. Considering the WHO statement of "no adverse health effects' the aim might have been to undermine the IARC decision and give the telecom industry a 'clean bill' of health (8). It might, however, be argued that as a result of the IARC classification, it was necessary for WHO to also look at other effects, and not just tumours.

\section{The WHO EMF project}

The biophysicist Michael Repacholi from Australia was the first chairman of ICNIRP in 1992. His own research within this field is scanty, although a study on lymphoma incidence in mice exposed to RF radiation published in 1997 has attracted interest (49). Repacholi suggested in 1995 that WHO should start the EMF project. This was adopted by WHO in 1996, see WHO Press office: WHO launches new international project 
to assess health effects of electric and magnetic fields; 4 June 1996 (50). Repacholi was during 1996-2006 the leader of the WHO department of electromagnetic radiation, the WHO EMF project.

The WHO EMF project is supposed to: 1) provide information on the management of EMF protection programs for national and other authorities, including monographs on EMF risk perception, communication and management; 2) provide advice to national authorities, other institutions, the general public and workers, about any hazards resulting from EMF exposure and any needed mitigation measures. (http://www. who.int/peh-emf/project/EMF_Project/en/index1.html).

Michael Repacholi immediately set up a close collaboration between WHO and ICNIRP (being head of both organizations) inviting the electric, telecom and military industries to meetings. He also arranged for large part of the WHO EMF project to be financed by the telecommunication industry's lobbying organisations; GSM Association and Mobile Manufacturers Forum, now called Mobile \& Wireless Forum (MWF) (51) in addition to WHO, see the International EMF Project, Progress Report June 2005-2006 (http://www.who.int/peh-emf/publications/reports/IAC_Progress_Report_2005-2006.pdf).

Repacholi acted like a representative for the telecom industry while responsible for the EMF health effects department at the WHO (http://microwavenews.com/news/ time-stop-who-charade). Since he left WHO in 2006 he has been involved in industry propaganda video interviews with GSM Association and Hydro Quebec (https://www.youtube. com/watch?v=fDZx7MphDjQ; https://www.youtube.com/ watch?v=1MI_fa5YsgY) where he clearly speaks in favor of the telecommunications and the power industries, respectively.

Michael Repacholi is still the Chairman emeritus at ICNIRP (http://www.icnirp.org/en/about-icnirp/emeritus-members/ index.html) and has propagated during almost 20 years worldwide the 'only thermal effect' paradigm of health risks from RF-EMF exposure, ignoring the abundant evidence for nonthermal effects or cancer risks.

Repacholi recruited Emilie van Deventer to the WHO EMF Project in 2000. She is the current project manager at WHO for the EMF project. She has been a long time member of the industry dominated organization Institute of Electrical and Electronics Engineers (IEEE). IEEE is the world's most powerful federation of engineers. The members are or have been employed in companies or organizations that are producers or users of technologies that depend on radiation frequencies, such as power companies, the telecom and the military industry. IEEE has prioritized international lobbying efforts for decades especially aimed at the WHO, for more information see (http://www.ices-emfsafety. org/wp-content/uploads/2016/10/Approved-Minutes-

TC95-Jan_16.pdf).

Van Deventer is an electrical engineer. She has no formal or earlier knowledge in medicine, epidemiology or biology, so it is surprising that she was selected for such an important position at the WHO (http://www.waves.utoronto.ca/ people_vandeventer.htm) (http://www.itu.int/ITU-T/worksem/ emc-emf/201107/bios.html).

The very same year she was recruited to the WHO EMF Project Toronto University Magazine wrote about Emilie van Deventer's work stating that it was 'invaluable' to industry:
'The software modelling done by teams like van Deventer's is invaluable.' 'The industrial community is very interested in our research capabilities,' says van Deventer. 'It always needs to be working on the next generation of products, so it turns to universities to get the research done.' (http://www.research. utoronto.ca/edge/fall2000/content2b.html).

The importance of this work is reflected in the research funding van Deventer and her team received from the Natural Sciences \& Engineering Research Council of Canada (NSERC), Communications \& Information Technology Ontario (CITO), and their major industrial partner, Nortel. 'We are fulfilling a very real need in the industry today, which will only increase as technology creates more opportunity. In the process, consumers will continue to enjoy faster computers, lighter cell phones, smaller electronic organizers and the vast array of other electronic gadgets the high-tech world has to offer.' (http://www.research.utoronto.ca/edge/edgenet/ fall2000/a-clear-signal/).

\section{WHO radio frequency fields: Environmental health criteria monograph}

Two years after the anticipated 'formal risk assessment' by WHO in 2012 a draft was launched in 2014 (http://www. who.int/peh-emf/research/rf_ehc_page/en/). It was open for public consultation until December 31, 2014, but is now closed according to the WHO home page.

It was stated that: 'The process used in developing the chapters is described in Appendix X. Note that the chapters 1,13 and 14 which will provide a summary, health risk assessment and protective measures are not available for this consultation. The drawing of conclusions from the literature and the drafting of these chapters is the remit of a formal Task Group that will be convened by WHO at a later stage in the process.'

It must be regarded to be unusual and scientifically inadequate not to provide for review the health risk assessment and protective measures which would be most important parts of the Monograph. Furthermore, it turned out that of the six members in the WHO Core Group four are active members of ICNIRP and one is a former member. This was published in 2016 (52) and also discussed more recently (8). Only one person seems to be independent of ICNIRP, see Table I. Several persons have also affiliation(s) to other advisory groups, authorities and/or committees. Six of the 20 additional experts are affiliated with ICNIRP.

Being a member of ICNIRP is a conflict of interest in the scientific evaluation of health hazards from RF radiation through ties to military and industry. This is particularly true since the ICNIRP guidelines are of huge importance to the influential telecommunications, military and power industries. Another conflict of interest is for members officially assessing possible health effects below their own set ICNIRP guidelines, which they have already stated as beeing safe, see also discussion in (52). Such persons would hardly have different opinions than those stated by ICNIRP. Critical views are not heard and a balanced scientific evaluation is not obtained.

It should be noted that the Ethical Board at the Karolinska Institute in Stockholm, Sweden concluded already in 2008 that being a member of ICNIRP may be a conflict of interest that 
Table I. Members of WHO Monograph core group and their involvement in different other groups (8).

\begin{tabular}{lccccc}
\hline Name & WHO & ICNIRP & UK/AGNIR & SSM & SCENIHR \\
\hline Simon Mann & $\mathrm{X}$ & $\mathrm{X}$ & $\mathrm{X}$ & & \\
Maria Feychting & $\mathrm{X}$ & $\mathrm{X}$ & $\mathrm{X}$ & $\mathrm{X}^{\mathrm{a}}$ & \\
Gunnhild Oftedal & $\mathrm{X}$ & $\mathrm{X}$ & & $\mathrm{X}$ & \\
Eric van Rongen & $\mathrm{X}$ & $\mathrm{X}$ & & $\mathrm{X}$ & $\mathrm{X}$ \\
Maria Rosaria Scarfi & $\mathrm{X}$ & $\mathrm{X}^{\mathrm{a}}$ & & & \\
Denis Zmirou & $\mathrm{X}$ & & & & \\
\hline
\end{tabular}

${ }^{a}$ Former. WHO, World Health Organization; ICNIRP, International Commission on Non-Ionizing Radiation Protection; AGNIR, Advisory Group on Non-Ionising Radiation; SSM, Strålsäkerhetsmyndigheten (Swedish Radiation Safety Authority); SCENIHR, Scientific Committee on Emerging and Newly Identified Health Risks.

should be stated officially whenever a member from ICNIRP makes opinions on health risks from EMF (Karolinska Institute diary number: 3753-2008-609). No statement of such conflict of interest can be found in the WHO draft of the Monograph on $\mathrm{RF}$ radiation.

Several persons and groups have sent critical comments to WHO on the many shortcomings in the draft of the Monograph on RF fields. In general WHO has not responded to these comments and it is unclear to what extent, if any, they are considered. Due to the short time for submission our (Lennart Hardell, Michael Carlberg) comments related only to section 12.1 Cancer Epidemiology. Our concluding remarks dated December 15, 2014 were: 'In conclusion the WHO draft is biased towards the null results. Findings on an association between use of wireless phones (mobile phones and cordless phones) and increased risk for brain tumours are misinterpreted, selectively reported and/or omitted in total. The draft cannot be used as science-based evaluation of increased risk. It needs to be re-written in a balanced way by scientists trained in epidemiology and oncology, not the least in medicine, and without conflicts of interest.'

Moreover, after the formal closing date for comments on the Monograph several additional submissions have been made to WHO. Professor Michael Kundi at Center for Public Health, Institute of Environmental Health, Vienna, Austria stated in his summary dated January 12, 2015: 'I was only able to check chapter 12 about cancer and only the epidemiological studies. While the EHC (Environmental Health Criteria) team did a great job in allocating the relevant literature with only few more recent papers missing, I'm not fully satisfied with the assessment of the evidence. There is a striking imbalance in the comments made on studies that were positive in contrast to those that were negative. Only the most obvious shortcomings of studies that didn't report an effect of exposure are mentioned while positive findings are often discussed at length, sometimes with very far-fetched assumptions about potential sources of bias. This is in marked contrast to other EHC monographs that are discussing the evidence in a way not to overlook a potential harmful effect. My comments, giving reference to the lines of the draft are detailed on the following pages.'

The BioInitiative Working Group issued December 19, 2016 a 'No Confidence' Letter to the WHO EMF Program
Manager: 'The BioInitiative Working Group urges the World Health Organization to make changes to the WHO RF EHC Core Group membership to more fairly reflect membership and expertise of the 2011 IARC RF Working Group. At present, the WHO RF EHC Core Group is indistinguishable from ICNIRP... undermining credibility of the process and ensuring doubt about conclusions... Even if schedule delays occur as a result, an acceptable outcome depends on public confidence. There [are] now many thousands of high quality scientific papers indicating possible non-thermal RF risks to health and those experts most competent by virtue of their research contributions are absent from this process... Both human and animal results are now available to incorporate in the RF EHC risk assessment. This important effort can only be assured with a more balanced composition of core participants in the process. As well, the membership needs to be inclusive of under-represented countries such as Russia, China, India, Turkey, and Iran whose research communities have produced the majority of studies on non-thermal effects of RF in recent years.' (http://www.bioinitiative.org/report/ wp-content/uploads/2016/12/BIWG-final-draft-WHO-RFEHC-Monograph-team-composition.pdf).

This letter was followed by another from the BioInitiative Working Group on January 24, 2017 including suggestion of experts to replace present persons in the Core Group and Additional Experts: 'We have not yet received a reply acknowledging our letter... It is important that the most knowledgeable panel of experts be appointed to prepare the RF EHC Monograph. At present, the EHC Core Group members uniformly represent attitudes and scientific positions of ICNIRP, an organization whose membership has steadfastly refused to accept new scientific evidence of potential health risks from non-thermal, low-intensity radiofrequency radiation despite recent scientific advances in knowledge on the subject. We are recommending substitutions for membership as indicated on the attached page. Please note that we are suggesting a complete replacement for those persons currently holding positions.' (http://www.bioinitiative.org/report/wp-content/ uploads/2017/01/BIWG-EHC-substitution-letter.pdf).

Call for Protection from Non-ionizing Electromagnetic Field Exposure was made by the International Electromagnetic Field Scientist Appeal, initial release date May 11, 2015, latest version's date January 29, 2017 with 222 signatures 
from 41 nations: 'We are scientists engaged in the study of biological and health effects of non-ionizing electromagnetic fields (EMF)... Effects include increased cancer risk, cellular stress, increase in harmful free radicals, genetic damages, structural and functional changes of the reproductive system, learning and memory deficits, neurological disorders, and negative impacts on general well-being in humans. Damage goes well beyond the human race, as there is growing evidence of harmful effects to both plant and animal life. These findings justify our appeal to the United Nations (UN) and, all member States in the world, to encourage the World Health Organization (WHO) to exert strong leadership in fostering the development of more protective EMF guidelines, encouraging precautionary measures, and educating the public about health risks, particularly risk to children and fetal development. By not taking action, the WHO is failing to fulfil its role as the preeminent international public health agency.' (https://www.emfscientist.org/index.php/emfscientist-appeal).

A press release was issued on February 24, 2017 by the European coordination of organizations for an EMF exposure regulation which truly protects public health. The European citizens' organizations failed, however, to include in their letter the conflict of interest associated with ICNIRP members assessing possible effects below set ICNIRP guidelines, see discussion above. They stated that: 'The Conflict of Interest Scandal is repeating itself in the WHO: European citizens' organizations uncover conflicts of interest between the health and radiofrequency WHO expert group and telecommunications or electric companies. Almost 40 organizations and European Platforms (which in turn include many regional, national or local social organizations), supported by the International EMF Alliance (IEMFA), denounce the flagrant conflict of interest of the Core Group of experts for drafting, in the current year, of a WHO Environmental Health Criteria Monograph on Radio-Frequency Fields...

The preponderant presence of members of the International Commission on Non-Ionizing Radiation Protection (ICNIRP) reminds us that this organization (and other institutions with the same criteria) refused to accept new scientific evidence of potential health risks from non-thermal, low-intensity radiofrequency radiation despite recent scientific advances in knowledge on the subject. The ICNIRP not only does not guarantee transparency or independence but conflicts of interest of its members are well known and reported, due to their relationships with telecommunications or electric companies, thereby undermining the impartiality that should govern the regulation of Public Exposure Standards for nonionizing radiation... By not taking action, the WHO is failing to fulfill its role as the preeminent international public health agency...' (http://www.peccem.org/DocumentacionDescarga/ Plataforma-Estatal/notasprensa/European.coordination.press. release-february-2017.pdf).

Letter dated March 1, 2017 from Russian National Committee on Non-Ionizing Radiation Protection to Maria Neira, Director, Public Health and Environment with copy to Dr. E. van Deventer, Public Health and Environment, WHO: 'It has just come to our attention that the WHO RF Working group consists mainly from present and past ICNIRP members. In general, the WG is not balanced and... the private self-elected organization ICNIRP, similar as majority of the current WHO RF WG members, does not recognize the non-thermal RF effects,... Thus, the guidelines of ICNIRP are irrelevant to present situation when majority of population over the world is chronically exposed to non-thermal RF from mobile communication.' (http://www.radiationresearch.org/articles/ rusncnirp-letter-to-who/), letter available at (http://www. mast-victims.org/resources/docs/RNCNIRP-letter-WHO/2017 _03_01.pdf).

\section{Human Health Effects of Non-Ionizing Radiation - Informal meeting at WHO March 3, 2017}

It is quite obvious that it would be of utmost value to learn what is on-going at WHO regarding the Monograph on RF radiation, especially since formal responses to submissions with comments are virtually absent. Thus, some 9 months after initial contact Dr Maria Neira accepted to organize a meeting, relating to the effects of electromagnetic fields on health, in her office at WHO in Geneva. The request for a meeting was made by independent researchers from different universities. An informal meeting was organized on March 3, 2017. (http://eceri-institute.org/fichiers/1490952497_newsletter_ECERI_5.pdf).

Dr Maria Neira is Director of the Public Health and the Environment Department at WHO. Present at the meeting was also Dr Emilie van Deventer, the Team Leader of the Radiation Programme at WHO which deals with non-ionizing and ionizing radiation topics related to human health. She has been working at WHO since 2000 where she heads the International EMF Project, the Ultraviolet INTERSUN Programme and the International Radon Project. Dr van Deventer received a Ph.D. in Electrical Engineering from the University of Michigan, USA. She was adjunct professor of Electrical and Computer Engineering, financed by the telecom industry, at the University of Toronto in Canada from 1992 to 2000. She is the WHO Observer on the Main Commission of ICNIRP, e.g. participating in ICNIRP meetings. (http://www.itu.int/en/ ITU-T/Workshops-and-Seminars/emf/201307/Pages/vanDEVENTERTaheraEmilie.aspx). She is also one of 8 members of the Swedish Radiation Safety Authority (SSM).

The allocated time at the WHO office was $1.5 \mathrm{~h}$. Dr Maria Neira opened the meeting stressing that it was not official but informal. She told that her department is very much interested in challenging science. In addition to myself, four additional experts were also present. The experts gave short presentations on health effects of RF radiation, biological effects from exposure to non-thermal RF radiation, overview of epidemiological studies on brain tumour risk, RF radiation and electromagnetic hypersensitivity (EHS), and finally epigenetic mechanisms by which children are especiallyvulnerable to RF radiation. Obviously the five presentations were very short in order to give time for discussions, the most important part of the meeting.

The participating team of five experts with considerable knowledge and own research within this area offered to collaborate with WHO, especially to finalize the WHO Monograph on RF radiation. Maria Neira stated clearly that no collaboration with WHO is to be considered, and further that she does not intend to have another meeting with the group. However, 
Table II. World Health Organization (Geneva, Switzerland) levels of RF-radiation March 3, $2017\left(\mu \mathrm{W} / \mathrm{m}^{2}\right)$ treating values at detection limit as $0 .{ }^{\text {a }}$

\begin{tabular}{|c|c|c|c|c|c|}
\hline & $\mathrm{n}$ & Mean & Median & Min & $\operatorname{Max}$ \\
\hline FM & 1,813 & 2.0 & 1.2 & 0.0 & 128.4 \\
\hline TV3 & 1,813 & 0.0 & 0.0 & 0.0 & 1.7 \\
\hline TETRA I & 1,813 & 0.1 & 0.0 & 0.0 & 136.7 \\
\hline TETRA II & 1,813 & 0.0 & 0.0 & 0.0 & 0.0 \\
\hline TETRA III & 1,813 & 0.0 & 0.0 & 0.0 & 3.2 \\
\hline TV4\&5 & 1,813 & 0.1 & 0.0 & 0.0 & 11.9 \\
\hline LTE 800 (DL) & 1,813 & 1.3 & 0.4 & 0.0 & 101.9 \\
\hline LTE 800 (UL) & 1,813 & 0.0 & 0.0 & 0.0 & 0.0 \\
\hline GSM + UMTS 900 (UL) & 1,813 & 0.0 & 0.0 & 0.0 & 4.7 \\
\hline GSM + UMTS 900 (DL) & 1,813 & 8.6 & 4.9 & 0.3 & 268.2 \\
\hline GSM 1800 (UL) & 1,813 & 0.3 & 0.0 & 0.0 & 182.1 \\
\hline GSM 1800 (DL) & 1,813 & 4.2 & 1.7 & 0.3 & 268.2 \\
\hline DECT & 1,813 & 0.3 & 0.1 & 0.0 & 38.2 \\
\hline UMTS 2100 (UL) & 1,813 & 0.0 & 0.0 & 0.0 & 0.4 \\
\hline UMTS 2100 (DL) & 1,813 & 4.5 & 2.5 & 0.4 & 199.1 \\
\hline WIFI 2G & 1,813 & 0.0 & 0.0 & 0.0 & 1.3 \\
\hline LTE 2600 (UL) & 1,813 & 0.0 & 0.0 & 0.0 & 0.0 \\
\hline LTE $2600(\mathrm{DL})$ & 1,813 & 0.0 & 0.0 & 0.0 & 0.6 \\
\hline WIMax & 1,813 & 0.0 & 0.0 & 0.0 & 0.0 \\
\hline WIFI 5G & 1,813 & 0.0 & 0.0 & 0.0 & 4.0 \\
\hline Total & 1,813 & 21.5 & 13.3 & 4.8 & 432.3 \\
\hline
\end{tabular}

${ }^{\mathrm{a}}$ Frequency bands and number (n) of readings are given.

she added that she is open to new data. She also said that there is no conflict of interest with ICNIRP since ICNIRP is a WHO collaborative organization. The scientific group, as above, was instead invited to send to WHO peer-reviewed publications, especially meta-analyses that would be the 'best gift'.

It was stated by the WHO officials that ICNIRP is an NGO with an official relationship with WHO that 'helps us a lot in our analyses' and their members work as WHO's experts. Thus, in spite of five of six persons in the Core Group for the Monograph being affiliated with ICNIRP, WHO seems to have no intention to change these members. On the other hand, the Task Group is not finalized. According to the meeting all experts are selected on individual basis and not as members of ICNIRP. Further, it was stated that the WHO guideline documents are in full WHO's responsibility. It is not known when the Monograph on $\mathrm{RF}$ radiation will be published. WHO still 'keeps looking at the evidence' and is still adding new documents to the Monograph.

The decision by the Ethical Board at the Karolinska Institute in Stockholm, Sweden from 2008 that being a member of ICNIRP may be a conflict of interest that should be stated in scientific publications was brought into attention during the meeting. WHO was unaware of that document and promised to 'look into it'. Obviously that conflict of interest applies to almost the whole Core Group of the Monograph, several members of additional experts, not to say Emilie van Deventer and thus the whole WHO EMF project and the Monograph on RF radiation.

\section{Exposure to RF radiation within the WHO building in Geneva}

In our on-going project on measurements of ambient RF radiation in some cities Geneva is part of the study. Results of parts of Stockholm, Sweden have been published $(16,17)$ and will be used e.g. for comparison with levels in the future due to further development of this technology. In Geneva also measurements within the WHO building; main entrance, some corridors and the meeting room were included. These previously unpublished results have been communicated to the representatives at WHO including that they will be published. There has been no reaction from the WHO.

An EME Spy 200 exposimeter with a valid calibration was used to collect the exposure data. The exposimeter measures 20 predefined frequency bands that cover frequencies from $88-5,850 \mathrm{MHz}$. The sampling time was every 4th sec which is the fastest for the given exposimeter, for further details see our publications. For frequency modulation (FM), TV3, TETRA, TV4\&5, Wi-Fi 2G and Wi-Fi 5G, the lower detection limit is $0.01 \mathrm{~V} / \mathrm{m}\left(0.27 \mu \mathrm{W} / \mathrm{m}^{2}\right)$; for all other bands, the lower detection limit is $0.005 \mathrm{~V} / \mathrm{m}\left(0.066 \mu \mathrm{W} / \mathrm{m}^{2}\right)(16,17)$.

The results, presented in Table II, show low mean total exposure level, $21.5 \mu \mathrm{W} / \mathrm{m}^{2}$, thus below the scientific benchmark of 30 to $60 \mu \mathrm{W} / \mathrm{m}^{2}$ that has been proposed to be the 'lowest observed effect level' (LOEL) for RF radiation, see Chapter 24 


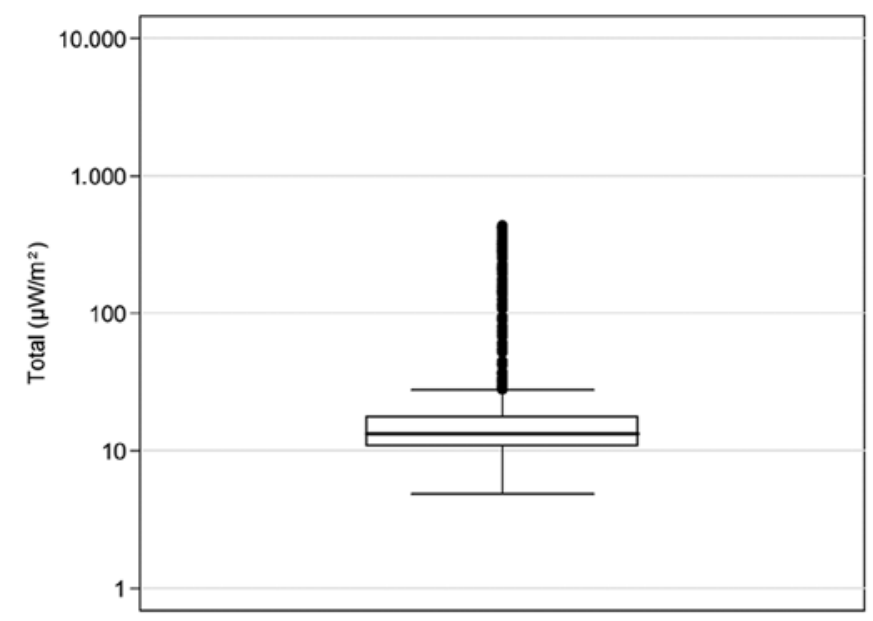

Figure 1. World Health Organization, 20 Avenue Appia, CH-1211 Geneva 27, Switzerland. Box plot for total exposure in $\mu \mathrm{W} / \mathrm{m} 2$, logarithmic scale. The median is indicated by a black line inside the box; the bottom and top of the boxes show first and third quartiles; the end of the whisker is calculated as $1.5 x I Q R$ (interquartile range). Points represent outliers.

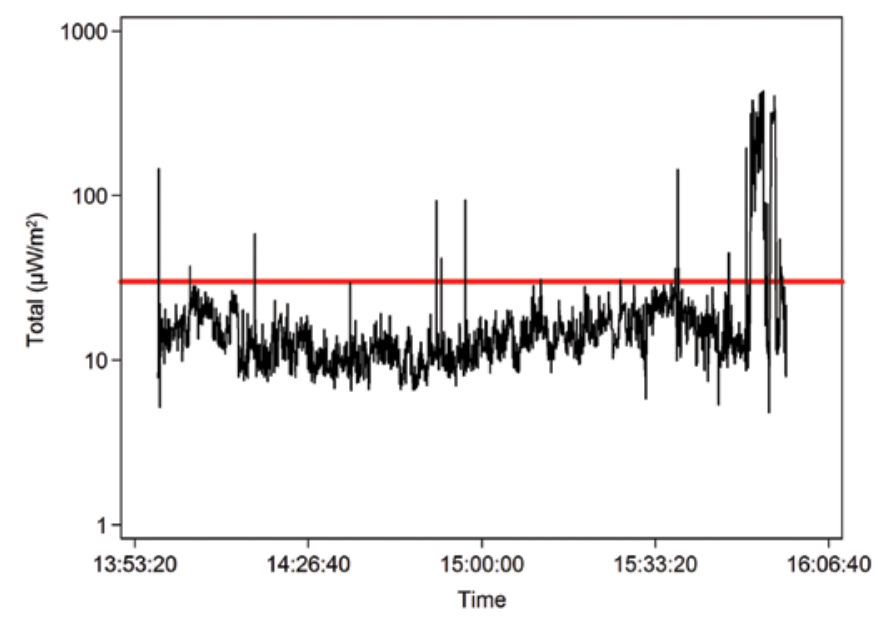

Figure 2. World Health Organization, Geneva, Switzerland. Total RF field exposure $\left(\mu \mathrm{W} / \mathrm{m}^{2}\right.$, mean exposure $=21.5 \mu \mathrm{W} / \mathrm{m}^{2}$, logarithmic scale $)$ over time of one exposure round, March 3, 2017 time 13:57:53-15:58:31. The horizontal line represents the LOEL exposure limit of $30 \mu \mathrm{W} / \mathrm{m}^{2}$ suggested by the Bioinitiative Report (21).

of the BioInitiative Report (21). Note that only for the mean it is possible to calculate the total as the sum of means of the individual frequency bands, mathematically this is not possible for median, min and max in Table II. The major sources were GSM + UMTS 900 DL (3G), GSM 1800 DL (2G) and UMTS 2100 DL (3G), i.e. downlink (DL) of RF radiation from outside base stations. The results for total exposure are also presented as box plot in Fig. 1. In Fig. 2 total exposure over time is presented. Almost all RF radiation was below $30 \mu \mathrm{W} / \mathrm{m}^{2}$, the LOEL of RF radiation for possible health risks as shown with the horizontal line. The highest peak level, $432.3 \mu \mathrm{W} / \mathrm{m}^{2}$, was measured at 15:54:07. Most contribution was from GSM 1800 (DL), $268.2 \mu \mathrm{W} / \mathrm{m}^{2}$, and UMTS 2100 (DL), $110.4 \mu \mathrm{W} / \mathrm{m}^{2}$. This was measured just inside the building at the entrance and represent $\mathrm{RF}$ radiation from base stations in the vicinity.

The exposure to RF radiation within the WHO building is very low compared to other measurements, for example our

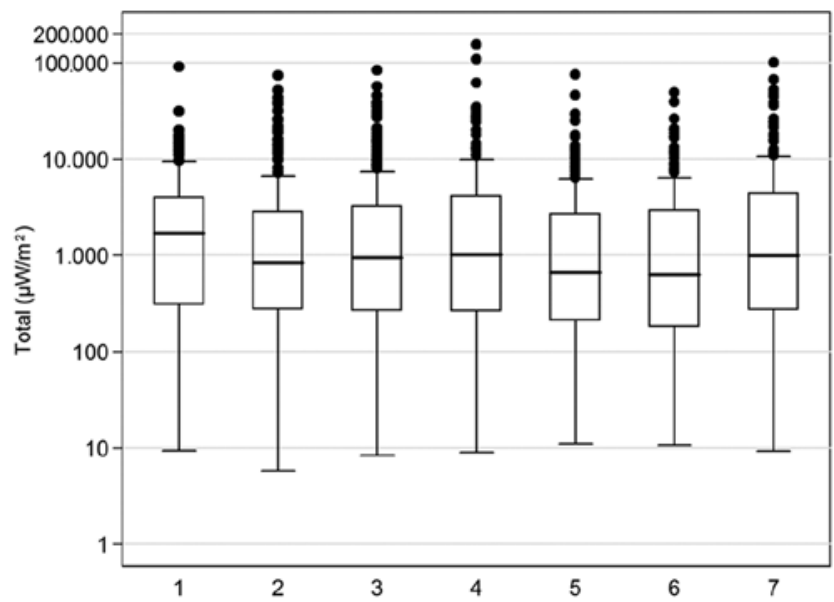

Figure 3. Box plot for total exposure in $\mu \mathrm{W} / \mathrm{m}^{2}$ for the seven measurement rounds in the Stockholm Central Railway Station (16). The median is indicated by a black line inside each box; the bottom and top of the boxes show first and third quartiles; the end of the whiskers are calculated as 1.5xIQR (interquartile range). Points represent outliers.

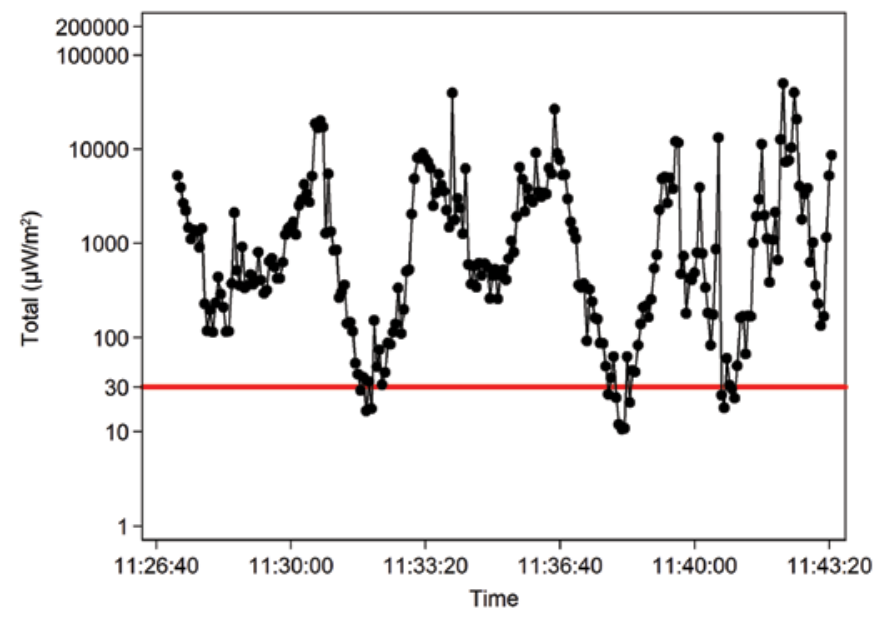

Figure 4. Total radiofrequency field exposure $\left(\mu \mathrm{W} / \mathrm{m}^{2}\right)$ of the lowest exposure round (November 9, 2015; mean exposure $2,817.0 \mu \mathrm{W} / \mathrm{m}^{2}$ ) by walking across the Stockholm Central Station (16). The line represents the exposure limit of $30 \mu \mathrm{W} / \mathrm{m}^{2}$ suggested by the Bioinitiative Report (21).

measurements inside the Stockholm Central station where people both are passing through but also are there for hours each day such as security and police staff, cafe workers, shop workers, janitors, information counter people, etc., see Figs 3 and 4. Here, the mean total exposure for the lowest exposure round was $2,817 \mu \mathrm{W} / \mathrm{m}^{2}$, mostly from down loading from GSM, $3 \mathrm{G}$ and $4 \mathrm{G}$ base stations (16). Thus, the measured mean level in the WHO building is more than 130 times lower than in the Stockholm Central Station.

\section{Concluding remarks}

The meeting at WHO was an obvious disappointment. During the discussion the two WHO officials showed little interest to collaborate with the scientists convened at the meeting in spite of the scientific evidence on adverse health effects. Their in-house experts seem to be members of ICNIRP, 
although not exclusively. This may explain why only shortterm thermal effects from RF radiation are accepted as proofs of harm, and why non-thermal biological effects are ignored. In the draft of the Monograph a large bulk of peer-reviewed scientific publications on non-thermal effects are dismissed, c.f. as also by ICNIRP (19). Most remarkable is that WHO has no intention to replace the Core Group of experts affiliated with ICNIRP. Thereby ICNIRP is given full access to and exclusive possibilities to influence the Monograph. In view of the huge economic interests built into the ICNIRP guidelines, and several of its expert members' ties to industry, no doubt this is a large conflict of interest that will seriously undermine not only the credibility of the Monograph on RF radiation but also the credibility of WHO as a protector of world health. Seriously enough, the Monograph will be the hallmark for years to come on evaluation of health hazards from RF radiation and pave the way for increasing exposure to RF radiation to people and environment, e.g. the fifth generation $(5 \mathrm{G})$, internet of things, etc.

Children and adolescents may be more sensitive to RF radiation than adults (2). Thus as an authoritative agency, WHO has an obligation to reference all the scientific research results and call the experts from all the related fields like engineering, health and medicine to engage in the re-evaluation of all health effects including non-thermal of RF radiation. Related agencies should launch an objective and transparent project for this assessment. The EMF project was started many years ago and many new wireless digital technologies are developed and new devices are popularizing with a very fast speed.

Protests and comments by scientific experts and several organizations seem to be ignored. The Monograph might be political and industry supportive more than scientific and health promoting. For a definitive conclusion a more thorough review of the whole draft document would be needed. By now it is time for laymen, NGOs and scientists to exert pressure on politicians to change the WHO agenda on RF radiation and health hazards and decide that WHO's purpose is to support world health instead of industry interests. It is also time to evaluate the competence of the persons making the evaluations and decisions before publishing the Monograph. Of note, evidence has been published (52) which indicated that members of ICNIRP have written scientifically incorrect and misleading information. It is unknown if WHO has responded to this evidence of suggested scientific misconduct.

To evaluate cancer risks it is necessary to include scientists with competence in medicine, especially oncology. Furthermore, what are the personal advantages, at least in the short time, for those refusing to accept peer-reviewed scientific publications on adverse effects on health and environment from RF radiation? Ironically enough, whether knowingly or not, the WHO staff seems to protect themselves from high involuntary RF radiation levels at least in the measured areas within the Geneva building.

\section{Acknowledgments}

The study was supported by grants from Mr. Brian Stein, Cancer - och Allergifonden, Cancerhjälpen.

\section{References}

1. Cardis E, Deltour I, Mann S, Moissonnier M, Taki M, Varsier N, Wake K and Wiart J: Distribution of RF energy emitted by mobile phones in anatomical structures of the brain. Phys Med Biol 53: 2771-2783, 2008.

2. Gandhi OP, Morgan LL, de Salles AA, Han Y-Y, Herberman RB and Davis DL: Exposure limits: The underestimation of absorbed cell phone radiation, especially in children. Electromagn Biol Med 31: 34-51, 2012.

3. Baan R, Grosse Y, Lauby-Secretan B, El Ghissassi F, Bouvard V, Benbrahim-Tallaa L, Guha N, Islami F, Galichet L and Straif K; WHO International Agency for Research on Cancer Monograph Working Group: Carcinogenicity of radiofrequency electromagnetic fields. Lancet Oncol 12: 624-626, 2011.

4. International Agency for Research on Cancer: IARC monographs on the evaluation of carcinogenic risks to humans, Volume 102. In: Non-Ionizing Radiation, Part 2: Radiofrequency Electromagnetic Fields. WHO Press, Lyon, France, 2013. Available online: http://monographs.iarc.fr/ENG/Monographs/ vol102/mono102.pdf. Accessed April 1, 2017.

5. Hardell L, Carlberg M, Söderqvist F and Hansson Mild K: Case-control study of the association between malignant brain tumours diagnosed between 2007 and 2009 and mobile and cordless phone use. Int J Oncol 43: 1833-1845, 2013.

6. Hardell L, Carlberg M and Hansson Mild K: Use of mobile phones and cordless phones is associated with increased risk for glioma and acoustic neuroma. Pathophysiology 20: 85-110, 2013.

7. Coureau G, Bouvier G, Lebailly P, Fabbro-Peray P, Gruber A, Leffondre K, Guillamo JS, Loiseau H, Mathoulin-Pélissier S, Salamon R, et al: Mobile phone use and brain tumours in the CERENAT case-control study. Occup Environ Med 71: 514-522, 2014.

8. Carlberg M and Hardell L: Evaluation of mobile phone and cordless phone use and glioma risk using the Bradford Hill viewpoints form 1965 on association or causation. BioMed Res Int 2017: 9218486, 2017.

9. Markovà E, Malmgren LO and Belyaev IY: Microwaves from mobile phones inhibit 53BP1 focus formation in human stem cells more strongly than in differentiated cells: Possible mechanistic link to cancer risk. Environ Health Perspect 118: 394-399, 2010.

10. Megha K, Deshmukh PS, Banerjee BD, Tripathi AK, Ahmed R and Abegaonkar MP: Low intensity microwave radiation induced oxidative stress, inflammatory response and DNA damage in rat brain. Neurotoxicology 51: 158-165, 2015.

11. Dasdag S, Akdag MZ, Erdal ME, Erdal N, Ay OI, Ay ME, Yilmaz SG, Tasdelen B and Yegin K: Effects of $2.4 \mathrm{GHz}$ radiofrequency radiation emitted from Wi-Fi equipment on microRNA expression in brain tissue. Int J Radiat Biol 91: 555-561, 2015.

12. Yakymenko I, Tsybulin O, Sidorik E, Henshel D, Kyrylenko O and Kyrylenko S: Oxidative mechanisms of biological activity of low-intensity radiofrequency radiation. Electromagn Biol Med 35: 186-202, 2016.

13. Akdag MZ, Dasdag S, Canturk F, Karabulut D, Caner Y and Adalier N: Does prolonged radiofrequency radiation emitted from Wi-Fi devices induce DNA damage in various tissues of rats? J Chem Neuroanat 75: 116-122, 2016.

14. Wyde M, Cesta M, Blystone C, Elmore S, Foster P, Hooth M, Kissling G, Malarkey D, Sills R, Stout M, et al: Report of Partial findings from the National Toxicology Program Carcinogenesis Studies of Cell Phone Radiofrequency Radiation in Hsd: Sprague Dawley® SD rats (Whole Body Exposures). US National Toxicology Program (NTP), 2016. doi: org/10.1101/055699. http://biorxiv.org/content/biorxiv/early/2016/05/26/055699.full. pdf. Accessed on April 1, 2017.

15. Hedendahl L, Carlberg M and Hardell L: Electromagnetic hypersensitivity - an increasing challenge to the medical profession. Rev Environ Health 30: 209-215, 2015.

16. Hardell L, Koppel T, Carlberg M, Ahonen M and Hedendahl L: Radiofrequency radiation at Stockholm Central Railway Station in Sweden and some medical aspects on public exposure to RF fields. Int J Oncol 49: 1315-1324, 2016.

17. Hardell L, Carlberg M, Koppel T and Hedendahl L: High radiofrequency radiation at Stockholm Old Town: An exposimeter study including the Royal Castle, Supreme Court, three major squares and the Swedish Parliament. Mol Clin Oncol 6: 462-476, 2017. 
18. International Commission on Non-Ionizing Radiation Protection: Guidelines for limiting exposure to time-varying electric, magnetic, and electromagnetic fields (up to $300 \mathrm{GHz}$ ). Health Phys 74: 494-522, 1998

19. International Commission on Non-Ionizing Radiation Protection: ICNIRP statement on the "Guidelines for limiting exposure to time-varying electric, magnetic, and electromagnetic fields (up to $300 \mathrm{GHz}$ '. Health Phys 97: 257-258, 2009.

20. BioInitiative Working Group: BioInitiative Report: A Rationale for a Biologically-based Public Exposure Standard for Electromagnetic Fields (ELF and RF). Sage C and Carpenter DO (eds). Bioinitiative, 2007. http://www.bioinitiative.org/table-ofcontents/. Accessed on April 1, 2017.

21. BioInitiative Working Group: BioInitiative 2012. A Rationale for a Biologically-based Exposure Standard for Electromagnetic Fields (ELF and RF). Sage C and CarpenterDO (eds). Bioinitiative, 2012. http://www.bioinitiative.org/table-of-contents/. Accessed on April 1,2017.

22. Buchner $\mathrm{K}$ and Eger $\mathrm{H}$ : Changes of clinically important neurotransmitters under the influence of modulated RF fields - A long-term study under real-life conditions. Umwelt-MedizinGesellschaft 24: 44-57, 2011 (In German). https://www.avaate. org/IMG/pdf/Rimbach-Study-20112.pdf.

23. Fragopoulou AF, Samara A, Antonelou MH, Xanthopoulou A Papadopoulou A, Vougas K, Koutsogiannopoulou E, Anastasiadou E, Stravopodis DJ, Tsangaris GT, et al: Brain proteome response following whole body exposure of mice to mobile phone or wireless DECT base radiation. Electromagn Biol Med 31: 250-274, 2012.

24. Nittby H, Brun A, Eberhardt J, Malmgren L, Persson BR and Salford LG: Increased blood-brain barrier permeability in mammalian brain 7 days after exposure to the radiation from a GSM-900 mobile phone. Pathophysiology 16: 103-112, 2009.

25. Tang J, Zhang Y, Yang L, Chen Q, Tan L, Zuo S, Feng H, Chen Z and Zhu G: Exposure to $900 \mathrm{MHz}$ electromagnetic fields activates the mkp-1/ERK pathway and causes blood-brain barrier damage and cognitive impairment in rats. Brain Res 1601: 92-101, 2015.

26. Abramson MJ, Benke GP, Dimitriadis C, Inyang IO, Sim MR, Wolfe RS and Croft RJ: Mobile telephone use is associated with changes in cognitive function in young adolescents. Bioelectromagnetics 30: 678-686, 2009.

27. Deshmukh PS, Nasare N, Megha K, Banerjee BD, Ahmed RS, Singh D, Abegaonkar MP, Tripathi AK and Mediratta PK: Cognitive impairment and neurogenotoxic effects in rats exposed to low-intensity microwave radiation. Int J Toxicol 34: 284-290, 2015.

28. Calvente I, Pérez-Lobato R, Núñez MI, Ramos R, Guxens M, Villalba J, Olea N and Fernández MF: Does exposure to environmental radiofrequency electromagnetic fields cause cognitive and behavioral effects in 10-year-old boys? Bioelectromagnetics 37: 25-36, 2016.

29. OECD: Students, Computers and Learning: Making the Connection PISA, OECD Publishing, 2015. http://www.oecd-ilibrary.org/ education/students-computers-and-learning_9789264239555-en. Accessed on April 1, 2017.

30. Spitzer M: Information technology in education: Risks and side effects. Trends Neurosci Educ 3: 81-85, 2014.

31. Hensinger P: Big data: A paradigm shift in education from personal autonomy to conditioning toward excessive consumerism. Umwelt-Medizin-Gesellschaft 28: 206-213, 2015

32. Roser K, Schoeni A, Foerster M and Röösli M: Problematic mobile phone use of Swiss adolescents: Is it linked with mental health or behaviour? Int J Public Health 61: 307-315, 2016.

33. Hardell L, Söderqvist F, Carlberg M, Zetterberg H and Hansson Mild K: Exposure to wireless phone emissions and serum $\beta$-trace protein. Int J Mol Med 26: 301-306, 2010.
34. Sangün Ö, Dündar B, Cömlekçi S and Büyükgebiz A: The effects of electromagnetic field on the endocrine system in children and adolescents. Pediatr Endocrinol Rev 13: 531-545, 2015.

35. Belyaev I, Dean A, Eger H, Hubmann G, Jandrisovits R, Kern M, Kundi M, Moshammer H, Lercher P, Müller K, et al: EUROPAEM EMF Guideline 2016 for the prevention, diagnosis and treatment of EMF-related health problems and illnesses. Rev Environ Health 31: 363-397, 2016.

36. Carter B, Rees P, Hale L, Bhattacharjee D and Paradkar MS: Association between portable screen-based media device access or use and sleep outcomes: A systematic review and metaanalysis. JAMA Pediatr 170: 1202-1208, 2016.

37. Thomas S, Heinrich S, von Kries R and Radon K: Exposure to radio-frequency electromagnetic fields and behavioural problems in Bavarian children and adolescents. Eur J Epidemiol 25: 135-141, 2010.

38. Divan HA, Kheifets L, Obel C and Olsen J: Cell phone use and behavioural problems in young children. J Epidemiol Community Health 66: 524-529, 2012

39. Herbert MR and Sage C: Autism and EMF? Plausibility of a pathophysiological link - Part I. Pathophysiology 20: 191-209, 2013.

40. Herbert MR and Sage C: Autism and EMF? Plausibility of a pathophysiological link part II. Pathophysiology 20: 211-234, 2013.

41. Sudan M, Olsen J, Arah OA, Obel C and Kheifets L: Prospective cohort analysis of cellphone use and emotional and behavioural difficulties in children. J Epidemiol Community Health: May 23 , 2016 (Epub ahead of print). doi: 10.1136/jech-2016-207419.

42. Avendaño C, Mata A, Sanchez Sarmiento CA and Doncel GF: Use of laptop computers connected to internet through Wi-Fi decreases human sperm motility and increases sperm DNA fragmentation. Fertil Steril 97: 39-45.e2, 2012.

43. Dasdag S, Taş M, Akdag MZ and Yegin K: Effect of long-term exposure of $2.4 \mathrm{GHz}$ radiofrequency radiation emitted from Wi-Fi equipment on testes functions. Electromagn Biol Med 34: 37-42, 2015.

44. Ong EK and Glantz SA: Tobacco industry efforts subverting International Agency for Research on Cancer's second-hand smoke study. Lancet 355: 1253-1259, 2000.

45. Michaels D (ed): Doubt is Their Product. How Industry's Assault on Science Threatens Your Health. Oxford University Press, New York, 2008.

46. McGarity TO and Wagner WE: Bending Science. How Special Interests Corrupt Public Health Research. Harvard University Press, Cambridge, London, 2008.

47. Oreskes N and Conway EM: Merchants of Doubt: How a Handful of Scientists Obscured the Truth on Issues from Tobacco Smoke to Global Warming. Bloomsbury Press, New York, 2010.

48. Walker MJ (ed): Corporate Ties that Bind. An Examination of Corporate Manipulation and Vested Interest in Public Health. Skyhorse Publishing, New York, 2017.

49. Repacholi MH, Basten A, Gebski V, Noonan D, Finnie J and Harris AW: Lymphomas in E mu-Pim1 transgenic mice exposed to pulsed $900 \mathrm{MHZ}$ electromagnetic fields. Radiat Res 147: 631-640, 1997.

50. WHO Launches New International Project to Assess Health Effects of Electric and Magnetic Fields. Press release WHO/42, June 4, 1996.

51. Leloup D: Téléphonie mobile: Trafic d'influence à l'OMS? Mediaattitudes, 2007. http://www.mediattitudes.info/2006/12/ trafic-dinfluence-loms.html. Accessed on April 1,2017.

52. Starkey SJ: Inaccurate official assessment of radiofrequency safety by the Advisory Group on Non-ionising Radiation. Rev Environ Health 31: 493-503, 2016. 